\title{
Mechatronic Device for Elbow Rehabilitation
}

\author{
Davide Fausti ${ }^{\mathrm{a}}$ and Gianluigi Petrogalli \\ ${ }^{1}$ Polibrixia, R\&D Department, 25123 Brescia, Italy
}

\begin{abstract}
This work proposes a mechatronic device for elbow rehabilitation. The realized therapy is based on continuous passive motion. A prototype was realized and design and dimensioning is here presented. Preliminary tests will be performed on non-pathological subjects to allow clinical experiments.
\end{abstract}

\section{Submitting the manuscript}

The advantages obtained by using automatic devices for rehabilitation include the ability to gain quantitative information about therapies in order to adapt it to the particular needs of patients [1]. Thanks to these mechatronic devices $[2,3]$, there is also the possibility of performing the therapy and the execution of exercises remaining autonomously at home or under a physiotherapist's supervision, which controls the precision of movements performed by patients [4].

Although the technology of communication systems and computer equipment are widely spread among the people of all ages, they are still subject to strong psychological resistance, especially by therapists [5].

The proposed device is classified as an automatic system suitable for both rehabilitation in passive mode (CPM, the person is totally "accompanied" by the machine), and in the active mode for patients $[3,6]$.
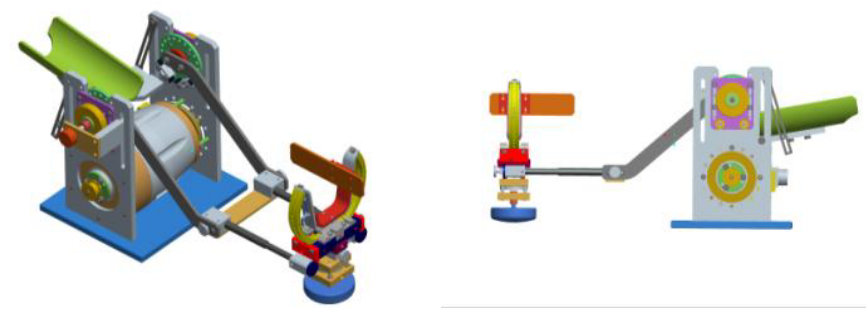

Figure 1. The mechanical device: CAD model.

Thanks to results obtained from preliminary tests (shown in paragraph 3) functional requirements have been defined for the device's control [7]. The definition of motion algorithms and their implementation are under development [8-12].

\footnotetext{
${ }^{\text {a }}$ Corresponding author : davide.fausti@polibrixia.it
} 
The objective is to provide the physiotherapist with a device that, in addition to reproducing the most used types of exercise in a precise [13-16] manner, allows to test new rehabilitation techniques and to quantify the results [17].

\section{Description of the mechanical structure}

The device has an architecture consisting of exoskeleton structure [18]. There are two vertical side plates fixed to a base support, between which, in the lower part, there is a direct drive brushless motor. In the upper part of the plates are hinged two parallel rods, which have the function to link with the appendix for the support of the wrist.

The patient puts the upper arm into the support positioned at the rear of the device (see the following Fig.2, number 1) and, using a special orthopedic glove, engages the wrist to the support positioned in front of the device (number 2 , in figure).

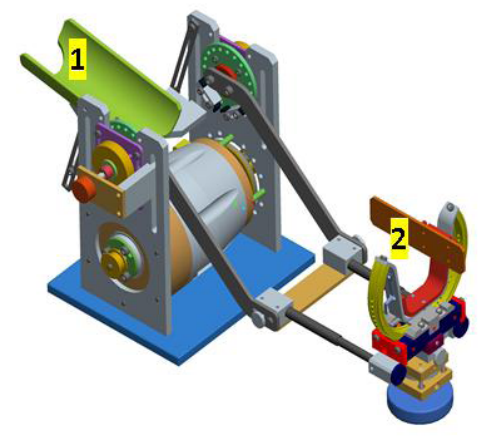

Figure 2. The mechanical device: CAD model.

The wrist support has a semicircular guide, that can rotate around its own axis, so as to allow the pronation-supination hand's movement.
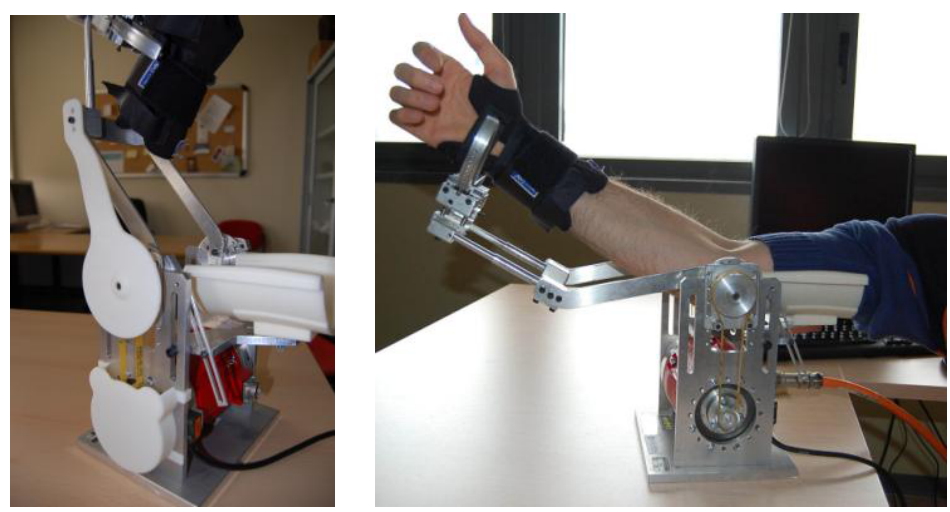

Figure 3. First prototype of the device.

The flexion-extension elbow's movement, as shown in following figure, is obtained thanks to a synchronous belt drive, having a $\tau=0.2$ transmission ratio. 


\section{SPbWOSCE-2015}

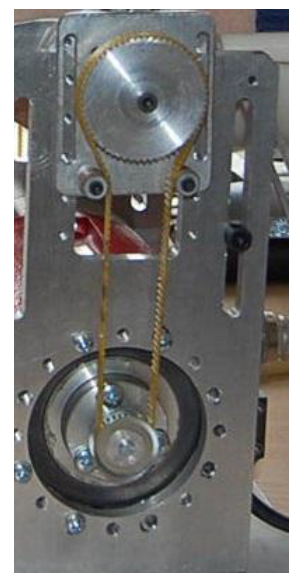

Figure 4. The transmission for flexion-extension.

Among different types of actuation: piezoelectric [19, 20], electric actuators [21-24], shape memory actuators $[2,16,25-29]$ and different other technologies, the choice was for a DC motor.

Pronation-supination movement is realized by a transmission with cables, sliding inside sheaths, and fixed to the ends of circular guide. They are driven by a little winch with DC motor.

This type of transmission [30] gives a good degree of compliance [31,32] to the system and allows to isolate motor from driven elements. Furthermore, with this architecture, is maintained as low as possible the masses connected to patient's arm, getting the advantage of a small inertia.

The presence of mechanical stops guarantees limitations to strokes of flexion-extension and pronationsupination movements. Moreover, in order to prevent dangerous situations [33, 34], in case of pronation-supination of the wrist, the device is equipped with a torque limiting clutch.

The transmission for elbow's flexion-extension is reversible, so as to allow the device to operate even in active mode.

The mechanical design has been performed according to ergonomic criteria and in accordance with the anthropometric parameters of the limb. There is a wide adaptation possibility to different articular dimensions.

The following image shows the different device's settings in order to adapt it to patient sizes.
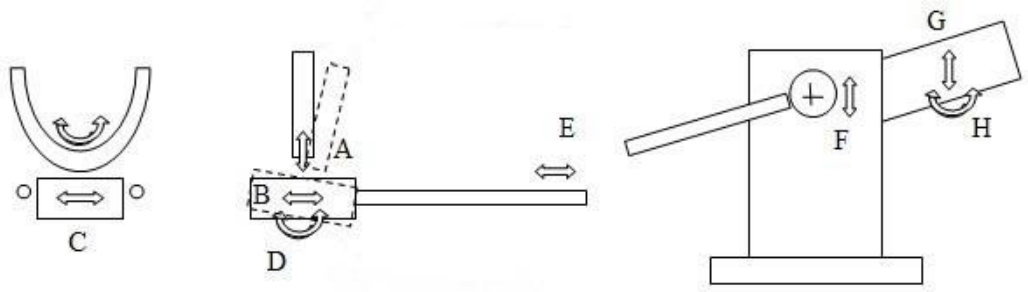

Figure 5. The transmission for flexion-extension.

They are:

A - vertical adjustment on the axis of pronation- supination (when device is stationary);

B - sliding wrist support to prevent a possible compression of the arm (either when the device is stationary or in motion); 
C - Transverse scrolling of the wrist support to accommodate the lateral movement of the hand during both flexion- extension and pronation - supination (to use as a setting when the device is stationary or, as a degree of freedom, when the device is working);

D - rotation of the wrist support (degree of freedom);

E - arm length adjustment (at stationary device);

$\mathrm{F}$ - axis adjustment of the drive pulley - tensioning system belt (the device is stopped);

$\mathrm{G}$ and $\mathrm{H}$ - adjustable positioning arm (the device is stopped).

Kinematical [35-41] an dynamical [42-44] aspects of the proposed device are not described in this work, where we prefer put the attention on the possibilities of use. Dimensioning is realized according with EU standard [45-48].

\section{Conclusions}

After a study of pathologies and associated treatments, we proposed a device for elbow rehabilitation. A prototype was dimensioned and realized according with biomedical standards. Some preliminary tests was realized to verify the possibility of applications on different class of patients exhibiting sufficient results for further researches.

\section{References}

[1] T. K. Hong and G. S. Kim, Journal of Institute of Control, Robotics and Systems, 19, 1011-1016, 2013

[2] F. Aggogeri, A. Borboni, and R. Faglia, Applied Mechanics and Materials, 373-375, 130-133, 2013

[3] A. Borboni, R. Faglia, and M. Mor, ASME 2014 12th Biennial Conference on Engineering Systems Design and Analysis ESDA 2014, 1, 1-10, 2014

[4] A. Karime, M. Eid, H. Dong, M. Halimi, W. Gueaieb, and A. E. Saddik, IEEE Transactions on Instrumentation and Measurement, 64, 427-438, 2015

[5] G. Taveggia, J. H. Villafañe, F. Vavassori, C. Lecchi, A. Borboni, and S. Negrini, Journal of Manipulative and Physiological Therapeutics, 37, 242-252, 2014

[6] C. Amici, A. Borboni, R. Faglia, D. Fausti, and P. L. Magnani, IEEE/RSJ International Conference on Intelligent Robots and Systems IROS, 2008, 735-740, 2008

[7] J. Adams, J. Roberts, K. Simms, D. Cheng, J. Hartman, and C. Bartlett, American Journal of Cardiology, 103, 762-765, 2009

[8] A. Borboni, M. Lancini, and R. Faglia, ASME 2014 12th Biennial Conference on Engineering Systems Design and Analysis ESDA 2014, 2, 1-7, 2014

[9] A. Borboni, R. Bussola, R. Faglia, P. L. Magnani, and A. Menegolo, Journal of Mechanical Design, Transactions of the ASME, 130, 0823011-0823016, 2008

[10] N. Vatin, N. Lavrov, A. Shipilov, Procedia Engineering, 117 (1), 374-380 (2015)

[11] B. Stamatovic, R. Upadhyay, and N. Vatin, Procedia Engineering, 2015, 660-667

[12] B. Melović, S. Mitrović, A. Djokaj, and N. Vatin, Procedia Engineering, 2015, 807-812

[13] F. Aggogeri, A. Borboni, A. Merlo, and N. Pellegrini, Advanced Materials Research, 590, 252257,2012

[14] A. Borboni, F. Aggogeri, N. Pellegrini, and R. Faglia, Advanced Materials Research, 590, 399404, 2012

[15] F. Aggogeri, A. Borboni, R. Faglia, A. Merlo, and S. De Cristofaro, Applied Mechanics and Materials, 336-338, 1170-1173, 2013

[16] A. Borboni and R. Faglia, Procedia Engineering, 2014, 1378-1381

[17] G. C. Burdea and C. Defais, Proceedings - IEEE Virtual Reality, 2013, 99-100

[18] S. K. Manna and S. Bhaumik, Journal of Robotics, 2013, 2013

[19] A. Borboni, D. De Santis, and R. Faglia, Proceedings of 8th Biennial ASME Conference on Engineering Systems Design and Analysis ESDA2006, 2006, 1-8, 2006 
[20] A. Borboni and R. Faglia, Journal of Applied Mechanics Transactions ASME, 80, 1-7, 2013

[21] S. F. Bart, T. A. Lober, R. T. Howe, J. H. Lang, and M. F. Schlecht, Sensors and Actuators, 14, 269-292, 1988

[22] I. Boldea and S. A. Nasar, IEEE Transactions on Energy Conversion, 14, 712-717, 1999

[23] K. Nakanoa, Y. Suda, and S. Nakadai, Journal of Sound and Vibration, 260, 213-235, 2003

[24] C. Q. Ru, X. Mao, and M. Epstein, Journal of the Mechanics and Physics of Solids, 46, 13011318,1998

[25] A. Borboni, R. Faglia, and M. Palpacelli, MESA 2014 - 10th IEEE/ASME International Conference on Mechatronic and Embedded Systems and Applications, 1, 1-7, 2014

[26] S. Pandini, A. Borboni, I. Bodini, D. Vetturi, D. Cambiaghi, K. Paderni, et al., AIP Conference Proceedings, 1599, 306-309, 2014

[27] S. Pandini, T. Riccò, A. Borboni, I. Bodini, D. Vetturi, D. Cambiaghi, et al., Journal of Materials Engineering and Performance, 23, 2545-2552, 2014

[28] M. Tiboni, A. Borboni, M. Mor, and D. Pomi, Proceedings of the Institution of Mechanical Engineers. Part I: Journal of Systems and Control Engineering, 225, 443-451, 2011

[29] A. Borboni, F. Aggogeri, N. Pellegrini, and R. Faglia, Advanced Materials Research, 590, $405-$ 410,2012

[30] Z. L. Sun, L. Y. Chen, Y. Zhang, and J. Y. Ding, Dongbei Daxue Xuebao/Journal of Northeastern University, 24, 548-551, 2003

[31] A. Borboni, D. De Santis, and R. Faglia, ASME 2010 10th Biennial Conference on Engineering Systems Design and Analysis ESDA2010, 2, 99-106, 2010

[32] A. Borboni and D. De Santis, Meccanica, 49, 1327-1336, 2014

[33] S. Nikolskiy, N. Vatin, O. Pertseva (2015) Journal of Applied Engineering Science, 13 (1), 11-18 (2015

[34] Z.Popović, L. Lazarevic, N. Vatin, Procedia Engineering, 117 (1), 846-853 (2015)

[35] A. Borboni, Proc of the IEEE International Conference on Fuzzy Systems, 1, 336-339, 2001

[36] G. Resconi, A. Borboni, R. Faglia, and M. Tiboni, Lecture Notes in Computer Science, 2178 LNCS, 352-368, 2001

[37] C. Amici, A. Borboni, P. L. Magnani, and D. Pomi, Proceedings of EUCOMES 2008 - The 2nd European Conference on Mechanism Science, 2008, 479-485, 2009

[38] C. Amici, A. Borboni, and R. Faglia, Advances in Mechanical Engineering, 2, 1-9, 2010

[39] A. Borboni, F. Aggogeri, and R. Faglia, ASME 2014 12th Biennial Conference on Engineering Systems Design and Analysis ESDA 2014, 3, 1-10, 2014

[40] A. Borboni, S. Pandini, D. Cambiaghi, M. Lancini, R. Adamini, R. Faglia, et al., ASME 2014 12th Biennial Conference on Engineering Systems Design and Analysis, ESDA 2014, 3, 1-6, 2014

[41] G. Palmieri, M. Callegari, L. Carbonari, and M. C. Palpacelli, MESA 2014 - 10th IEEE/ASME International Conference on Mechatronic and Embedded Systems and Applications, Conference Proceedings, 2014

[42] A. Borboni, R. Bussola, R. Faglia, and M. Tiboni, Proceedings of the 2004 Eleventh World Congress in Mechanism and Machine Science, 1, 1-5, 2004

[43] C. Amici, A. Borboni, P. L. Magnani, and D. Pomi, Proceedings of EUCOMES 2008 - The 2nd European Conference on Mechanism Science, 2008, 487-493, 2009

[44] J. H. Villafañe, P. Pillastrini, and A. Borboni, Journal of Chiropractic Medicine, 12, 176-181, 2013

[45] L. Solazzi, R. Scalmana, R. Adamini, R. Faglia, and A. Borboni, Agricultural Engineering International: CIGR Journal, 16, 102-112, 2014

[46] T. Kandikjan, J. J. Shah, and J. K. Davidson, CAD Computer Aided Design, 33, 721-737, 2001

[47] B. W. Olesen, M. Koschenz, and C. Johansson, ASHRAE Transactions, 2003, 656-668

[48] V.V Okrepilov, V.N. Krutikov, G.I. El'kin, Measurement Techniques, 57 (2),109-116 (2014) 